\title{
Thiobaca trueperi gen. nov., sp. nov., a phototrophic purple sulfur bacterium isolated from freshwater lake sediment
}

\footnotetext{
${ }^{1}$ University of Canberra and CRCFE/Murray-Darling Freshwater Research Centre, PO Box 921, Albury, NSW 2640, Australia

2 Department of Biological Sciences, University of Waikato, Hamilton, New Zealand

${ }^{3}$ Department of Microbiology and Immunology, University of Melbourne, Parkville, Victoria 3010, Australia

${ }^{4}$ Max-Planck-Institute for Marine Microbiology, Celsiusstraße 1, D-28359 Bremen, Germany

${ }^{5}$ GBF-Gesellschaft für Biotechnologische Forschung $\mathrm{mbH}$, Mascheroder Weg 1, D-38124, Braunschweig, Germany
}

\author{
Gavin N. Rees, ${ }^{1}$ Christopher G. Harfoot, ${ }^{2}$ Peter H. Janssen, ${ }^{3}$ \\ Liesbeth Schoenborn, ${ }^{3}$ Jan Kuever ${ }^{4}$ and Heinrich Lünsdorf ${ }^{5}$
}

\author{
Author for correspondence: Gavin Rees. Tel: +6126058 2356. Fax: +61260431626. \\ e-mail: gavin.rees@csiro.au
}

Two strains of a novel species of phototrophic micro-organism were isolated from the sediments of a shallow, freshwater, eutrophic lake. Both strains grew photolithoheterotrophically with sulfide as an electron donor, transiently accumulating intracellular sulfur globules. Photolithoautotrophic growth was not observed. One strain was designated $\mathrm{BCH}^{\mathrm{T}}$ (the type strain) and was studied in most detail. Cells contained bacteriochlorophyll $a$, and the dominant carotenoid was lycopene. Cell suspensions were brown. The photosynthetic membranes had a vesicular arrangement. Acetate, propionate, pyruvate, succinate and fumarate were each used as electron donors and carbon sources in the presence of sulfide and bicarbonate. In the presence of light, growth did not occur with hydrogen, thiosulfate or iron(II). The optimum temperature for growth was between 25 and $30^{\circ} \mathrm{C}$, the maximum being $36^{\circ} \mathrm{C}$. The $\mathrm{G}+\mathrm{C}$ content of the genomic DNA of strain $\mathrm{BCH}^{\mathrm{T}}$ was $63 \mathrm{~mol} \%$. Analysis of the 16S RNA genes showed that both strains belonged to the $\gamma$-subclass of the Proteobacteria but were phylogenetically distinct from any described phototrophic organisms within the Chromatiaceae. On the basis of phylogenetic and physiological differences from other phototrophic microorganisms, strain $\mathrm{BCH}^{\mathrm{T}}$ is described as a novel species of a new genus, Thiobaca trueperi gen. nov., sp. nov.

Keywords: Thiobaca trueperi, phototrophic bacteria, freshwater lakes

\section{INTRODUCTION}

Many investigations into the presence of phototrophic bacteria in aquatic ecosystems have been stimulated by conspicuous coloured accumulations occurring in anoxic waters or surface mud (Pfennig \& Trüper, 1992; Pfennig, 1987). If sulfide is produced at depth in aquatic environments, populations of purple and green phototrophic bacteria can grow by using the sulfide as an electron donor for photosynthesis; this often leads to prolific communities of phototrophic organisms (Sorokin, 1970; Takahashi \& Ichimura, 1970; Overmann et al., 1996). Other phototrophic bacteria that do not use sulfide, but instead use a range of reduced organic compounds as electron donors, also occur in

The GenBank/EMBL/DDBJ accession numbers for the 16S rRNA sequences of strains $\mathrm{BCH}^{\top}$ (=DSM $\left.13587^{\top}=\mathrm{ATCC} B A A-132^{\top}\right)$ and OCH-PHB (=DSM $13588=$ ATCC BAA-133) are respectively AJ404006 and AJ404007. freshwater systems (Imhoff \& Trüper, 1992). These phototrophs tend not to form dense, coloured blooms, but numerous studies have demonstrated their presence in a wide variety of freshwater ecosystems. In this study, we examined sediments of a freshwater lake that undergoes summer stratification. The lake has extensive growth of macrophytes, leading to a high carbon loading in the lake, resulting in apparently high rates of methane formation in the sediments. Since previous observations indicated the methanogenic nature of the study site, we examined the presence of phototrophic bacteria growing with relatively low levels of sulfide. Enrichment cultures led to the purification of brown-coloured organisms that were shown subsequently to be related to purple sulfur bacteria. Phylogenetic and physiological studies showed that the organisms differed significantly from any described in the literature, and we conclude that the strains represent a novel species of a new genus. We 
propose the name Thiobaca trueperi gen. nov., sp. nov., to encompass these novel strains.

\section{METHODS}

Source of organisms. Normans Lagoon is a eutrophic oxbow lake that is between 2 and $4 \mathrm{~m}$ deep and is situated adjacent to the River Murray, Albury, Australia. The lake has areas of open water surrounding beds of the emergent macrophyte Eleocharis sphacelata. Beds of Brasenia schreberi are associated with the edges of the lake, and portions of the surface often show growth of the aquatic fern Azolla. The lake is fringed, in part, by river red gums (Eucalyptus camaldulensis). Sediment was collected from the open-water regions, and enrichment cultures were made by adding $0.5 \mathrm{ml}$ wet sediment to $10 \mathrm{ml}$ basal medium (see below) that contained acetate $(5 \mathrm{mM})$, malate $(5 \mathrm{mM})$ and sulfide $(0.5 \mathrm{mM})$. Enrichment cultures were subcultured several times and pure cultures were obtained by application of the agar-shake dilution method (Pfennig, 1978).

Growth conditions. Basal medium (Biebl \& Pfennig, 1981) was used throughout this study and contained $\left(\mathrm{g}^{-1}\right.$ distilled water): $\mathrm{KH}_{2} \mathrm{PO}_{4}(0 \cdot 5), \mathrm{MgSO}_{4} \cdot 7 \mathrm{H}_{2} \mathrm{O}(0 \cdot 2), \mathrm{NaCl}(0 \cdot 4)$, $\mathrm{NH}_{4} \mathrm{Cl}(0 \cdot 4), \mathrm{CaCl}_{2} \cdot 2 \mathrm{H}_{2} \mathrm{O}(0.05)$ and yeast extract $(0 \cdot 2$, Oxoid). Basal medium was prepared and dispensed into Hungate tubes or $30 \mathrm{ml}$ serum bottles, with $\mathrm{N}_{2}$ as the headspace gas, as described by Rees et al. (1995). Bicarbonate was added to culture vessels after autoclaving to give a final concentration of $30 \mathrm{mM}$. Sodium sulfide was added to give a final concentration of either 0.5 or $1.5 \mathrm{mM}$, depending on the desired growth conditions. The final $\mathrm{pH}$ of the medium was between $7 \cdot 2$ and $7 \cdot 4$. Additional carbon sources were added to the medium from sterile anoxic stock solutions. Organic compounds were prepared as anoxic solutions, which were generally sterilized by autoclaving. Sodium pyruvate, carbohydrates, sodium thiosulfate and sodium sulfite were filter-sterilized through $0.2 \mu \mathrm{m}$ pore-size membrane filters. A vitamin solution (Widdel \& Bak, 1992) containing vitamin $B_{12}$ was added to sterile medium to give a final concentration of $50 \mu \mathrm{g}$ vitamin $\mathrm{B}_{12} \mathrm{l}^{-1}$. Cultures were routinely incubated at $25^{\circ} \mathrm{C}$, with illumination provided by tungsten lamps giving a light intensity of 120-140 lux.

Cellular and physiological characterization. All physiological tests were carried out in basal medium. When growth with organic compounds was not unequivocal, strains were subcultured into medium containing the same substrate. Photoautotrophy and vitamin requirements were examined by subculturing strains through five successive passages in the appropriate media.

When testing the use of ferrous iron as an electron donor for phototrophic growth, a solution of $\mathrm{FeSO}_{4}$ was prepared under anoxic conditions and added to the medium to give a final concentration of $5 \mathrm{mM}$. Sufficient sodium bicarbonate was added to the medium to ensure that the $\mathrm{pH}$ was maintained following addition of the iron(II) solution.

To test the ability to fix atmospheric nitrogen, a $1 \%(\mathrm{v} / \mathrm{v})$ inoculum was used to transfer cells through three successive subcultures in basal medium without yeast extract or ammonium chloride, but with nitrogen in the headspaces of the culture bottles. After the third subculture, in addition to continued subculturing of the cells in the yeast extract/ammonium chloride-free medium, the latter cells were used to inoculate two further experimental systems, which subsequently were serially passaged. The additional growth conditions were yeast extract-/ammonium chloride-free medium with argon in the headspace and ammoniumcontaining medium with argon in the headspace.

Whole-cell spectra were obtained as described by Pfennig \& Trüper (1992). For acetone extracts, cells were collected on glass-fibre filters and extracted overnight in the dark at $4{ }^{\circ} \mathrm{C}$. Scans were obtained using a Cary 3 (Varian) spectrophotometer. Photosynthetic pigments were analysed by HPLC as described previously (Dilling et al., 1995).

Phase-contrast micrographs were prepared by immobilizing cells on agar-coated slides and examining the slides with a Zeiss Axioskop microscope. Nile blue A (Ostle \& Holt, 1982) was used to determine whether cells contained lipid inclusions. For electron microscopy studies, exponentialphase cells of strain $\mathrm{BCH}^{\mathrm{T}}$ were chemically fixed with $2.5 \%$ $(\mathrm{v} / \mathrm{v})$ glutaraldehyde in the carbonate-buffered growth medium ( $\mathrm{pH} 7 \cdot 0)$ at ambient temperature for 5 days. Fixed cells were immobilized in $2 \%(\mathrm{w} / \mathrm{v})$ Noble agar (Difco). Cubes $\left(1 \mathrm{~mm}^{3}\right)$ of immobilized cells were cut and then washed three times for $10 \mathrm{~min}$ each at room temperature with $100 \mathrm{mM}$ cacodylate buffer $(\mathrm{pH} 7 \cdot 3)$. Post-fixation with $1 \%(\mathrm{w} / \mathrm{v}) \mathrm{OsO}_{4} / 100 \mathrm{mM}$ cacodylate buffer $(\mathrm{pH} 7 \cdot 3)$, further preparation steps and electron microscope analysis were done according to Yakimov et al. (1998).

DNA base composition and phylogenetic analyses. The $\mathrm{G}+\mathrm{C}$ content $(\mathrm{mol} \%$ ) of the genomic DNA was determined by HPLC as described by Janssen et al. (1996). The 16S rRNA genes of the novel strains were sequenced and the sequence data used to infer evolutionary relationships between these strains and other bacteria, as described by Janssen \& O'Farrell (1999). Evolutionary analyses were carried out using software implemented in the Australian Genomic Information Service (ANGIS) system (Littlejohn et al., 1996). The 16S rRNA gene sequences were compared with known 16S rRNA gene sequences by carrying out a BLAST analysis (Altschul et al., 1990) in the GenBank database (Benson et al., 2000), allowing the identification of close relatives. The gene sequences from the two novel strains and selected reference sequences (identified by the BLAST analyses and by comparisons of the inferred phylogenies determined in other studies; Guyoneaud et al., 1998; Imhoff et al., 1998) were aligned using the PILEUP program. The alignment was then checked manually and edited, using the secondary structure of the Escherichia coli 16S rRNA (Neefs et al., 1993) as a template. Regions for which homology could not be determined were eliminated from the entire dataset; these were helices 10 and 11, the terminal loops of helices 16,29 and 43 and part of the basal region of helix P23-1 (helix numbering is that of Neefs et al., 1993). In addition, $5^{\prime}$ and $3^{\prime}$ termini for which sequence information was lacking for one or more of the sequences were not used in the phylogenetic analyses. Evolutionary distances between pairs of edited sequences were determined according to the nucleotide substitution model of Jukes \& Cantor (1969), implemented in the EDNADIST program in the ANGIS system. Phylogenetic trees were reconstructed on the basis of these evolutionary distances by using the EFITCH program, which uses a least-squares method devised by Fitch \& Margoliash (1967), based on 1203 unambiguously aligned nucleotide positions, with a random order input and the global rearrangement option, as implemented in the ANGIS system. The 16S rRNA gene of Escherichia coli was used as an outgroup. The significance of each node was tested by bootstrap analysis (1000 data resamplings) as described elsewhere (Janssen \& O'Farrell, 1999). Maximum-parsi- 
mony and maximum-likelihood analyses were performed using the EDNAPARS and EDNAML programs in the ANGIS system.

\section{RESULTS}

\section{Isolation of strains}

Enrichment cultures transferred to agar-shake dilution tubes yielded a variety of colony types. Two strains were subsequently purified from brown-coloured colonies and were designated strain $\mathrm{BCH}^{\mathrm{T}}$ and strain $\mathrm{OCH}-\mathrm{PHB}$. Early growth experiments showed that both strains grew with sulfide and acetate but not malate, and the latter was subsequently eliminated from the routine subculturing medium. Liquidmedium cultures stored in the dark at $4{ }^{\circ} \mathrm{C}$ required subculture within 2 months, as longer incubation led to lysis and loss of culture viability. Cultures formed capsule material during stationary phase, which held the cells in a loose aggregation. Invariably, experiments showed that the physiological properties of strains $\mathrm{BCH}^{\mathrm{T}}$ and $\mathrm{OCH}-\mathrm{PHB}$ were almost identical and that these strains possess only minor differences in their 16S rRNA gene sequence. For this reason, strain $\mathrm{BCH}^{\mathrm{T}}$ was studied in most detail and is described here as the type strain of a novel species in a new genus.

\section{Morphological characteristics}

Cells of strains $\mathrm{BCH}^{\mathrm{T}}$ and $\mathrm{OCH}-\mathrm{PHB}$ were $1.5 \mu \mathrm{m}$ in diameter and 3-4.5 $\mu \mathrm{m}$ in length (Fig. 1). Cells of both strains often occurred in pairs, division occurring by binary fission. Rapid, single-directional motility consistent with flagella-driven motility was observed. No evidence for gliding motility was seen. The cells stained

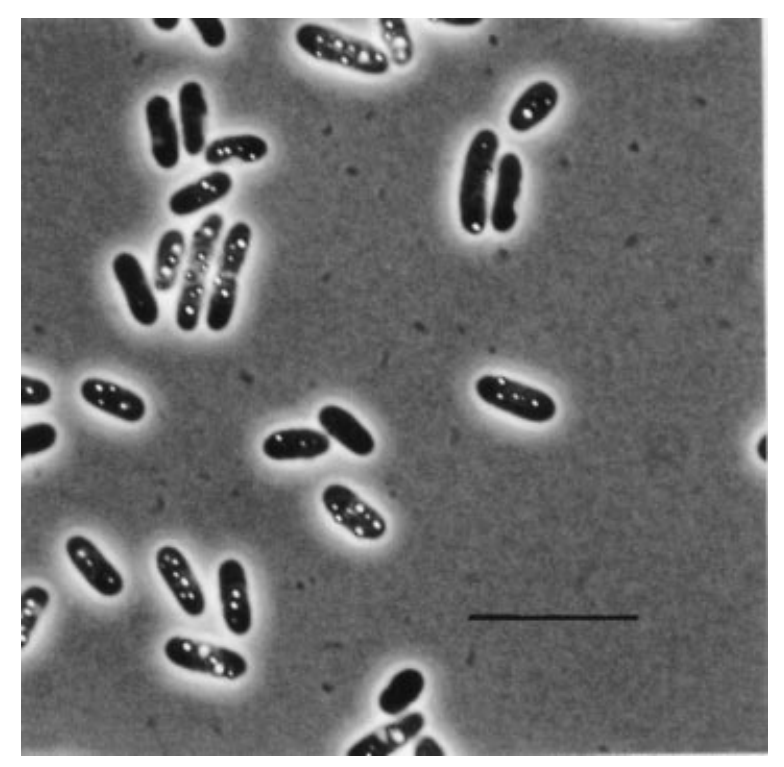

Fig. 1. Phase-contrast micrograph of cells of Thiobaca trueperi strain $\mathrm{BCH}^{\top}$ containing refractile sulfur globules. Bar, $10 \mu \mathrm{m}$.
Gram-negative. The cells produced opaque intracellular inclusions that had intense fluorescence after staining with Nile blue A, indicating that the inclusions were poly-3-hydroxybutyrate. Gas vesicles were never observed. The distinct morphology and cellular ultrastructure were apparent in cells growing exponentially under anaerobic and photoheterotrophic conditions (Fig. 2a,b). Besides the prominent, electron-translucent, spherical deposits of poly-3-hydroxybutyrate, dark-stained inclusions of varying dimensions were also recognized (Fig. 2, rhombus). These electrondense inclusions obviously represent paracrystalline bodies since, to a certain extent, they showed a regular periodic substructure (Fig. 2c; white arrowheads) with edge-angles of approximately $120^{\circ}$. Often, these inclusions were connected or surrounded by an amorphous, particulate, dark cytoplasmic substance, which may represent precursor material used for the synthesis of the inclusion (Fig. 2c; open arrowhead). The cytoplasm was characterized by the presence of large numbers of vesicles (Fig. 2c, d; v) of medium electron transparency, with a mean diameter of $40 \cdot 1 \pm 3.9 \mathrm{~nm}(n$ $=44)$. Thin sections confirmed a rather thick, Gramnegative cell wall that had an overall thickness of $61 \cdot 1 \pm 5 \cdot 6 \mathrm{~nm}(n=27)$, supplemented by an $\mathrm{S}$ layer (Fig. 2d, e; sl). This S layer was generally present on most of the cells (Fig. 2a; single arrowhead), but was occasionally absent from others (Fig. 2a; double arrowheads). Characteristically, the $\mathrm{S}$ layer showed a triple-layered organization, the individual layers being of similar thickness (approx. $13 \mathrm{~nm}$ ) (Fig. 2e; S1, S2, S3).

\section{Photosynthetic pigments}

Cultures of strain $\mathrm{BCH}^{\mathrm{T}}$ were brown. Absorption maxima of in vivo preparations occurred at 380, 462, 489, 524, 598, 805 and $875 \mathrm{~nm}$. The peaks at 380, 598, 805 and $875 \mathrm{~nm}$ demonstrate the presence of bacteriochlorophyll $a$ (Fig. 3). The in vivo bacteriochlorophyll absorption maxima that occurred at 805 and $875 \mathrm{~nm}$ shifted to $773 \mathrm{~nm}$ when extraction was in acetone: water $(90 \%: 10 \%, \mathrm{v} / \mathrm{v})$. The absorption maxima at 462, 489 and $524 \mathrm{~nm}$ indicate that lycopene and rhodopin are present. Analysis of cell extracts by HPLC confirmed that the dominant carotenoid was lycopene. Other carotenoids were present in small quantities and were not analysed further.

\section{Physiological characteristics}

Strain $\mathrm{BCH}^{\mathrm{T}}$ grew photoheterotrophically under anoxic conditions. When agar-shake tubes were incubated with the caps open (atmospheric conditions), strain $\mathrm{BCH}^{\mathrm{T}}$ grew only in the very deepest parts of the tubes. Heterotrophic growth did not occur in the absence of light. In the presence of sulfide and bicarbonate, the following compounds were used as growth substrates (tested at $5 \mathrm{mM}$ final concentration): acetate, propionate, fumarate, succinate, lactate and pyruvate. Substrates that were not used included formate, 

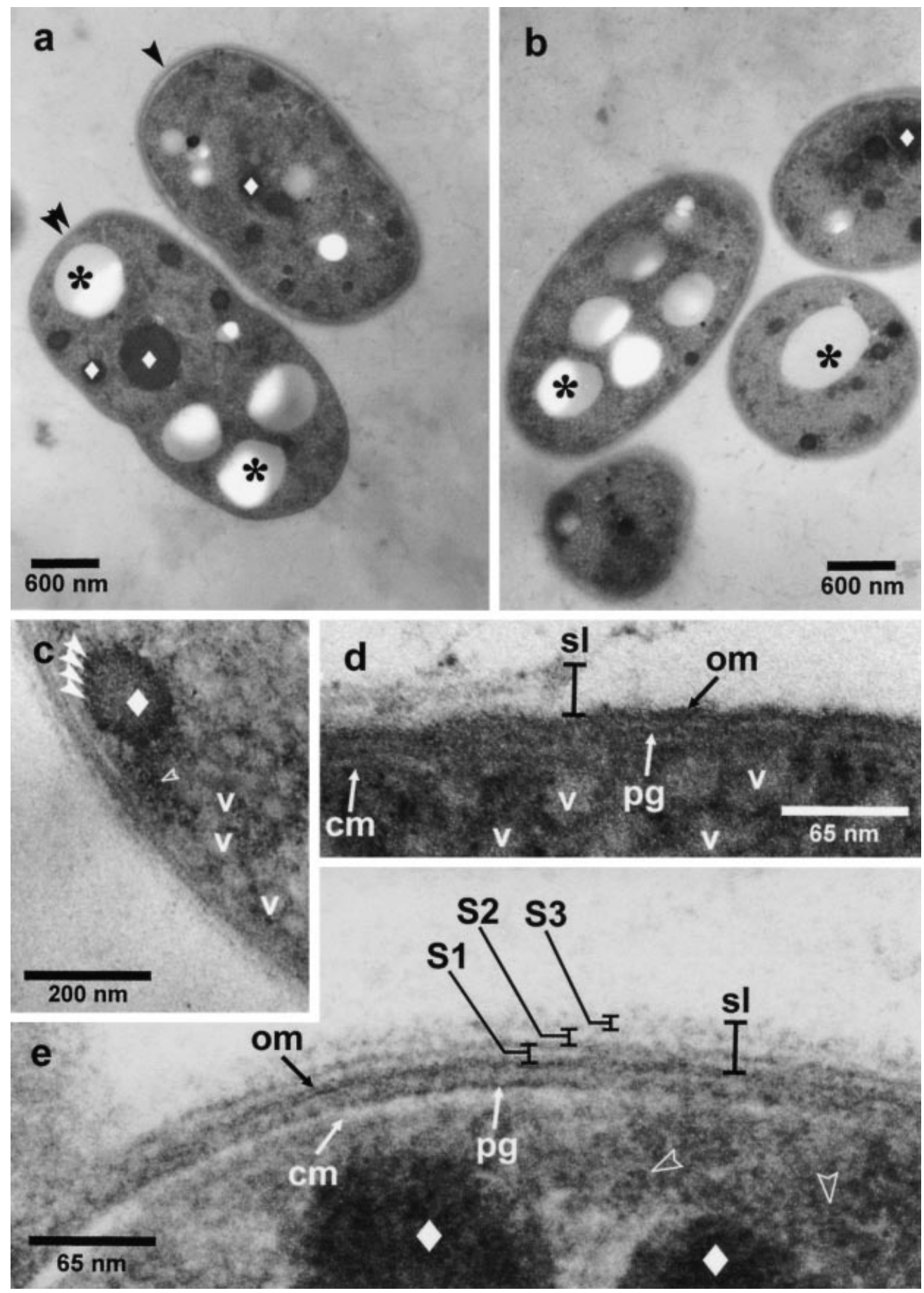

Fig. 2. Ultrastructure of Thiobaca trueperi strain $\mathrm{BCH}^{\top}$. (a, b) Transversely and longitudinally sectioned cells, which contain electron-translucent poly-3-hydroxybutyrate inclusions (asterisks) and dark inclusions of various sizes (rhombuses). Double arrowheads indicate a cell that has lost its $S$ layer, whereas a single arrowhead points to the $S$ layer of a second cell. (c) The cytoplasm characteristically contains densely packed, electron-translucent vesicles (v). Dark inclusions, which often appear dark-rimmed, are characterized by periodic elements (white arrowheads) and are surrounded by an amorphous, dark, cytoplasmic substance (open arrowhead). (d) The S layer (sl) is partially present on the left. (e) Details of the cell wall. The overall thickness of the $S$ layer is shown (bar labelled 'sl') and the triple-layered substructure is indicated $(\mathrm{S} 1, \mathrm{~S} 2, \mathrm{~S} 3)$. The cytoplasmic membrane $(\mathrm{cm})$ surrounds the cytoplasm, the murein layer $(\mathrm{pg})$ is densely stained and the outer membrane (om) shows the typical 'double-track' features. 


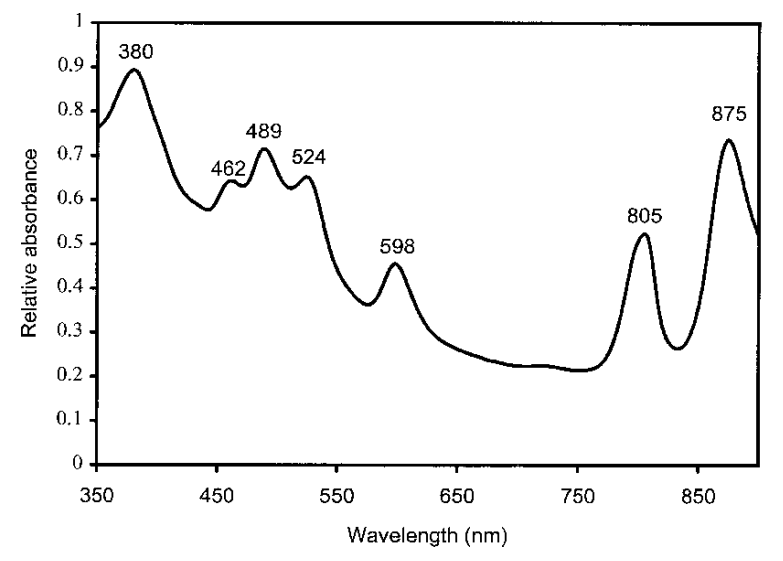

Fig. 3. Whole-cell spectral scan of strain $\mathrm{BCH}^{\top}$.

butyrate, valerate, palmitate, benzoate, ethanol, malate, citrate and glucose.

Strain $\mathrm{BCH}^{\mathrm{T}}$ stored intracellular sulfur globules when incubated in the presence of hydrogen sulfide, and the sulfur globules were utilized upon extended incubation. No growth occurred with thiosulfate or molecular hydrogen. Both strains grew in the presence of iron(II) plus acetate; however, growth occurred at the expense of acetate, and iron(II) was not oxidized. No growth occurred in medium containing iron(II) without acetate. Growth occurred in medium containing up to $2.5 \%(\mathrm{w} / \mathrm{v}) \mathrm{NaCl}$, optimum growth occurring between 0 and $0.5 \%(\mathrm{w} / \mathrm{v}) \mathrm{NaCl}$. The optimum temperature for growth was between 25 and $30^{\circ} \mathrm{C}$, and $36^{\circ} \mathrm{C}$ was the maximum temperature at which growth occurred. Although nitrogen fixation was not demonstrated by acetylene-reduction or ${ }^{15} \mathrm{~N}_{2}$ studies, strain $\mathrm{BCH}^{\mathrm{T}}$ continued to grow after five subcultures in medium with atmospheric nitrogen as the only nitrogen source. Similarly, growth occurred in ammonium-containing medium with argon in the headspace, but no growth occurred in ammonium-free medium under an argon atmosphere.

\section{DNA base composition}

The DNA base compositions for strains $\mathrm{BCH}^{\mathrm{T}}$ and OCH-PHB were respectively $62.9(\mathrm{SD}=0 \cdot 67, n=5)$ and $63 \cdot 9(\mathrm{SD}=0 \cdot 04, n=5) \mathrm{mol} \% \mathrm{G}+\mathrm{C}$.

\section{Phylogeny}

Fig. 4 shows a dendrogram depicting the phylogenetic relationships of strains $\mathrm{BCH}^{\mathrm{T}}$ and $\mathrm{OCH}-\mathrm{PHB}$ within the family Chromatiaceae. Including other reference sequences or eliminating some resulted in some changes to the branching order, but these changes were only ever at nodes where bootstrap values were less than $70 \%$. Maximum-parsimony and maximum-likelihood analyses maintained those clusters that were found using distance methods and supported by high bootstrap values. These clusters were (i) strains $\mathrm{BCH}^{\mathrm{T}}$ and OCH-PHB, (ii) the three Thiocapsa species, (iii) strain Thd2, Lamprocystis roseopersicina and Lamprocystis purpurea, (iv) the four Thiocystis species, the two Allochromatium species, Thermochromatium tepidum and Chromatium okenii, (v) the two Marichromatium species and (vi) Rhabdochromatium marinum and Thiorhodovibrio winogradskyi. The order of branching was different, however, from that obtained using distance methods (data not shown). The low bootstrap confidences ascribed to the nodes between the clusters in the distance analyses, and the intracluster coherence but lack of stability in the intercluster relationships obtained in maximum-parsimony and maximum-likelihood analyses, suggest that the six clusters are phylogenetically coherent groupings and do not point to a closer relationship for strains $\mathrm{BCH}^{\mathrm{T}}$ and $\mathrm{OCH}-$ PHB with respect to any one of the other five clusters.

The pairing of strains $\mathrm{BCH}^{\mathrm{T}}$ and $\mathrm{OCH}-\mathrm{PHB}$ separately from all other groupings was maintained and supported by all analyses (100\% bootstrap). The $16 \mathrm{~S}$ rRNA genes of strains $\mathrm{BCH}^{\mathrm{T}}$ and OCH-PHB had only 14 differences over the 1367 common nucleotide positions analysed. The Jukes-Cantor-corrected evolutionary distances to the closest relatives were as follows: $4 \cdot 2$, $7 \cdot 8$ and $6.0 \%$ for Thiocapsa roseopersicina, Thiocapsa rosea and Thiocapsa pendens, respectively; and 5.0, 5.6 and $5.3 \%$ for L. roseopersicina, L. purpurea and strain Thd 2 , respectively.

\section{DISCUSSION}

Normans Lagoon is an oxbow lake that contains extensive macrophyte growth and riparian vegetation. The consequence is that the lake sediments receive high organic carbon loads, leading to significant methanogenic activity in the sediments. The apparent domination of terminal oxidation by methanogenic organisms, as compared to sulfate-reducing species, led us to include only low levels of sulfide in the enrichment medium in the presence of malate and acetate (substrates commonly used by non-sulfur phototrophic micro-organisms; Imhoff \& Trüper, 1992). The resulting brown-coloured pure cultures isolated after enrichment with this medium, namely strains $\mathrm{BCH}^{\mathrm{T}}$ and $\mathrm{OCH}-\mathrm{PHB}$, were subsequently shown to be able to use sulfide as an electron donor for phototrophic growth. These strains were characterized and found to display characteristics of members of the family Chromatiaceae.

Phylogenetic analyses of the 16S rRNA gene sequences of strains $\mathrm{BCH}^{\mathrm{T}}$ and $\mathrm{OCH}-\mathrm{PHB}$ indicated that the two strains were closely related ( $98.7 \%$ similarity) and that both strains were members of the family Chromatiaceae. However, the calculated evolutionary distances do not support a closer relationship with any particular genus included in our analyses. Strains $\mathrm{BCH}^{\mathrm{T}}$ and $\mathrm{OCH}-\mathrm{PHB}$ shared very similar morpho- 


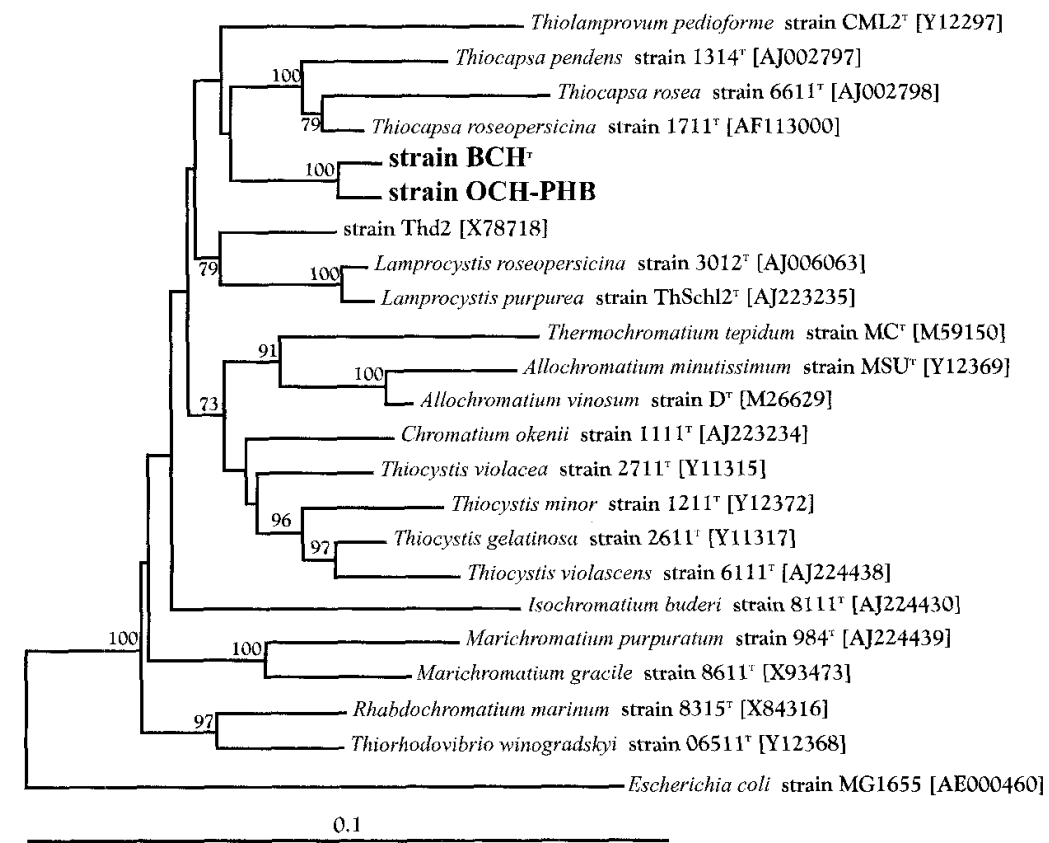

Fig. 4. Dendrogram depicting the phylogenetic relationships of strains $\mathrm{BCH}^{\top}$ and OCH-PHB within the family Chromatiaceae, determined from 16S rRNA gene sequence analysis from pairwise evolutionary distances constructed using a least-squares method. Bar, 0.1 inferred nucleotide substitutions per nucleotide position. Numbers given at the nodes represent bootstrap percentage values (1000 analyses, values of less than $70 \%$ not shown). GenBank/EMBL/DDBJ accession numbers are given in brackets.

Table 1. Summary of characteristics of Thiobaca trueperi and related phototrophic bacteria

Taxa are listed as: 1 , Thiobaca trueperi $\mathrm{BCH}^{\mathrm{T}} ; 2$, Thiocapsa roseopersicina $1711^{\mathrm{T}} ; 3$, Thiocapsa pendens $1314^{\mathrm{T}} ; 4$, Thiocapsa rosea $6611^{\mathrm{T}} ; 5$, Thiolamprovum pedioforme CML2 ${ }^{\mathrm{T}} ; 6$, Lamprocystis roseopersicina $3012^{\mathrm{T}} ; 7$, Lamprocystis purpurea ThSch $12^{\mathrm{T}} ; 8$, strain Thd2. Data were taken from this study and from Guyoneaud et al. (1998) (Thiocapsa species), Eichler \& Pfennig (1988)

(Thiolamprovum pedioforme), Pfennig et al. (1968) (Lamprocystis roseopersicina), Eichler \& Pfennig (1986) and Tindall (1999) (Lamprocystis purpurea) and Ehrenreich \& Widdel (1994) (strain Thd2). All taxa listed contain bacteriochlorophyll $a$ and utilize acetate and pyruvate.

\begin{tabular}{|c|c|c|c|c|c|c|c|c|}
\hline Characteristic & 1 & 2 & 3 & 4 & 5 & 6 & 7 & 8 \\
\hline Cell morphology & Rod & Spherical & Spherical & Spherical & $\begin{array}{l}\text { Spherical } \\
\text { to oval }\end{array}$ & Spherical & $\begin{array}{l}\text { Spherical } \\
\text { to oval }\end{array}$ & Rod \\
\hline Aggregate pattern & Single or pairs & $\begin{array}{l}\text { Tetrads, small } \\
\text { irregular aggregates }\end{array}$ & $\begin{array}{l}\text { Irregular } \\
\text { aggregates }\end{array}$ & $\begin{array}{l}\text { Irregular } \\
\text { aggregates }\end{array}$ & Platelets & $\begin{array}{l}\text { Diplococci or long } \\
\text { chains of } \\
\text { aggregates }\end{array}$ & $\begin{array}{r}\text { Single or forming } \\
\text { irregular clumps }\end{array}$ & $\begin{array}{l}\text { Single or forming } \\
\text { irregular aggregates }\end{array}$ \\
\hline \multicolumn{9}{|l|}{ Cell size $(\mu \mathrm{m})$ : } \\
\hline Diameter & $1 \cdot 6$ & $1 \cdot 0-3 \cdot 0$ & $1 \cdot 5-2 \cdot 0$ & $2 \cdot 0-3 \cdot 0$ & $2 \cdot 0$ & $3-3 \cdot 5$ & $1 \cdot 9-2 \cdot 3$ & $1 \cdot 3$ \\
\hline Length & $3-4 \cdot 5$ & - & - & - & $2 \cdot 0-3 \cdot 0$ & - & $2 \cdot 0-3 \cdot 2$ & $2 \cdot 0-3 \cdot 0$ \\
\hline Gas vesicles & No & No & Yes & Yes & Yes & Yes & Yes & Yes \\
\hline Carotenoid & Lycopene & Spirilloxanthin & Spirilloxanthin & Spirilloxanthin & Spirilloxanthin & Lycopenal & Okenone & $\mathrm{NR}$ \\
\hline Colour of cell suspension & Brown & Pink-red & Pink-red & Pink-red & Pink to rose-red & Purple & Purple-red & $\begin{array}{l}\text { Purple to } \\
\text { brownish red }\end{array}$ \\
\hline $\mathrm{G}+\mathrm{C}$ content $(\mathrm{mol} \%)$ & $62 \cdot 9$ & $65 \cdot 3$ & $65 \cdot 3$ & $64 \cdot 3$ & $65 \cdot 5$ & $63 \cdot 8$ & $63 \cdot 5$ & $\mathrm{NR}$ \\
\hline \multicolumn{9}{|l|}{ Substrates used: } \\
\hline Hydrogen & - & + & - & - & - & NR & - & + \\
\hline Hydrogen sulfide & + & + & + & + & + & + & + & - \\
\hline Thiosulfate & - & + & + & + & + & $+^{*}$ & + & - \\
\hline Formate & - & - & - & - & - & $-*$ & + & - \\
\hline Propionate & + & + & + & + & - & $+^{*}$ & + & - \\
\hline Malate & - & + & + & - & - & $-*$ & - & - \\
\hline Succinate & + & + & - & - & - & $-^{*}$ & - & - \\
\hline Fumarate & + & + & - & - & - & $-^{*}$ & - & - \\
\hline Glucose & - & - & + & - & - & $+^{*}$ & + & + \\
\hline Glycerol & - & + & - & - & - & $-*$ & - & NR \\
\hline
\end{tabular}

* B. Eichler and N. Pfennig (personal communication).

NR, Not reported.

logical properties but differed from their closest relatives (Table 1). The predominant morphology of Thiocapsa species, L. purpurea and Thiolamprovum pedioforme is spherical or spherical to oval-shaped cells, whereas the novel strains occur predominantly as rod-shaped cells. Thiocapsa species, L. purpurea and Thiolamprovum pedioforme also produce varied cell aggregates (Eichler \& Pfennig, 1986; Pfennig \& Trü- 
per, 1992; Imhoff, 2001). A loose form of aggregation occurred in strain $\mathrm{BCH}^{\mathrm{T}}$ but the aggregation was only associated with stationary-phase cultures.

Like other members of the Chromatiaceae, strains $\mathrm{BCH}^{\mathrm{T}}$ and $\mathrm{OCH}-\mathrm{PHB}$ possess bacteriochlorophyll $a$. The carotenoids present in members of the Chromatiaceae are diverse. The dominant carotenoid in Thiocapsa roseopersicina, Thiocapsa pendens, Thiocapsa rosea and Thiolamprovum pedioforme is spirilloxanthin, whereas $L$. purpurea possesses okenone and $L$. roseopersicina possesses lycopenal. Strains $\mathrm{BCH}^{\mathrm{T}}$ and $\mathrm{OCH}-\mathrm{PHB}$, in contrast, possess lycopene.

Strain $\mathrm{BCH}^{\mathrm{T}}$ possesses the vesicular arrangement of internal photosynthetic membranes characteristic of members of the family Chromatiaceae. We also observed dark-stained inclusions that morphologically resemble the 'polyhedral bodies' or 'carboxysomes' that have been described for Thiobacillus neapolitanus (Shively et al., 1973) and the cyanobacterium Gloeothece (Golecki \& Heinrich, 1991). However, the 'membrane' that surrounds the carboxysomes in Thiobacillus neapolitanus was not observed in strain $\mathrm{BCH}^{\mathrm{T}}$. Although a high constitutive level of autotrophic enzymes was found in Thiobacillus neapolitanus (Kuenen \& Beudeker, 1982), it is questionable whether the inclusions we observed would represent 'carboxysomes' sensu stricto, given the heterotrophic growth conditions used. Furthermore, because these inclusions did not show electron-dense contrast in unstained samples, and since no iron could be detected by electron energy-loss spectroscopy, they are not similar to the magnet-sensitive inclusions found in Ectothiorhodospira shaposhnikovii and Rhodopseudomononas palustris (Vainshtein et al., 1997). The exact nature of the dark-stained inclusions remains unknown at this stage.

Strain $\mathrm{BCH}^{\mathrm{T}}$ differs in a number of physiological aspects from its nearest relatives (Table 1). Both Thiocapsa roseopersicina and strain $\mathrm{BCH}^{\mathrm{T}}$ are able to use a relatively diverse range of organic compounds, but strain $\mathrm{BCH}^{\mathrm{T}}$ is unable to use hydrogen. Strain $\mathrm{BCH}^{\mathrm{T}}$ also differs from Thiocapsa roseopersicina in its inability to use thiosulfate. Strain $\mathrm{BCH}^{\mathrm{T}}$ shares some physiological characteristics with other representatives of the genus Thiocapsa, such as the ability to use acetate and pyruvate; however, these characteristics appear to be spread widely across this group of phototrophic bacteria and so cannot be used as discriminatory characteristics. Strain $\mathrm{BCH}^{\mathrm{T}}$ is able to use succinate and fumarate but not thiosulfate, whereas the opposite applies to Thiocystis species. Strain Thd 2 is closely related to strain $\mathrm{BCH}^{\mathrm{T}}$ but possesses several physiological characteristics that distinguish it from strain $\mathrm{BCH}^{\mathrm{T}}$. Strain Thd2 is able to oxidize iron(II), hydrogen and sulfide when the latter is supplied as iron sulfide, but it cannot use free sulfide or thiosulfate. Strain $\mathrm{BCH}^{\mathrm{T}}$ is unable to use iron(II).

Evolutionary analyses do not support a closer relationship between our novel strains and members of any genus of the currently described phototrophic sulfur bacteria. Similarly, morphological and physiological characteristics do not lend support to the inclusion of strains $\mathrm{BCH}^{\mathrm{T}}$ and $\mathrm{OCH}-\mathrm{PHB}$ in any of the currently described genera. We therefore propose that the latter strains represent a novel species of a new genus, Thiobaca trueperi gen. nov., sp. nov.

\section{Description of Thiobaca gen. nov.}

Thiobaca (Thi.o.ba'ca. Gr. n. thios sulfur; L. fem. n. baca berry, especially an olive; N.L. fem. n. Thiobaca, a berry with sulfur).

Cells are rod-shaped, occurring as single cells or in pairs. Motility is consistent with the presence of flagella. Cells stain Gram-negative. Division is by binary fission. Bacteriochlorophyll $a$ and carotenoids are present. The internal photosynthetic membrane is of the vesicular type. Grows photolithoheterotrophically or photoorganoheterotrophically under anoxic conditions with sulfide as electron donor. Sulfur globules are accumulated transiently inside cells. The type species is Thiobaca trueperi.

\section{Description of Thiobaca trueperi sp. nov.}

Thiobaca trueperi (true'pe.ri. N.L. gen. n. trueperi of Trüper, named after Hans G. Trüper, a German microbiologist who has made a significant contribution to our knowledge of anoxygenic phototrophic bacteria).

Cells are rod-shaped, $1.5 \mu \mathrm{m}$ in diameter, 3-4.5 $\mu \mathrm{m}$ long and motile. Gas vesicles are not formed. Cell suspension is brown in colour. Photosynthetic membranes are of the vesicular type. Contains bacteriochlorophyll $a$. Lycopene is the dominant carotenoid. Sulfate is not assimilated. Uses hydrogen sulfide as an electron donor for photolithoheterotrophic growth. Sulfur globules are stored inside the cells as intermediate products. No growth occurs with hydrogen, thiosulfate or iron(II). Acetate, propionate, pyruvate, succinate and fumarate are used in the presence of sulfide and bicarbonate. The optimum temperature for growth is between 25 and $30^{\circ} \mathrm{C}$, the maximum being $36{ }^{\circ} \mathrm{C}$. The $\mathrm{G}+\mathrm{C}$ content of the DNA is $63 \mathrm{~mol} \%$ The habitat is freshwater sediment. The type strain is strain $\mathrm{BCH}^{\mathrm{T}}$. Strains $\mathrm{BCH}^{\mathrm{T}}$ and $\mathrm{OCH}-\mathrm{PHB}$ have respectively been deposited at the DSMZ as DSM $13587^{\mathrm{T}}$ and DSM 13588 and at the ATCC as ATCC BAA-132 and ATCC BAA-133.

\section{ACKNOWLEDGEMENTS}

This work was supported by the University of Canberra (grant 98/474) and the Cooperative Research Centre for Freshwater Ecology (project B400).

\section{REFERENCES}

Altschul, S. F., Gish, W., Miller, W., Myers, E. W. \& Lipman, D. J. (1990). Basic local alignment search tool. J Mol Biol 215, 403-410. 
Benson, D. A., Karsch-Mizrachi, I., Lipman, D. J., Ostell, J., Rapp B. A. \& Wheeler, D. L. (2000). GenBank. Nucleic Acids Res 28, 15-18. Biebl, H. \& Pfennig, N. (1981). Isolation of members of the family Rhodospirillaceae. In The Prokaryotes, a Handbook on Habitats, Isolation and Identification of Bacteria, pp. 267-273. Edited by M. P. Starr, H. Stolp, H. G. Trüper, A. Balows \& Schlegel H. G. New York: Springer.

Dilling, W., Liesack, W. \& Pfennig, N. (1995). Rhabdochromatium marinum gen. nom. rev., sp. nov., a purple sulfur bacterium from a salt marsh microbial mat. Arch Microbiol 164, 125-131.

Ehrenreich, A. \& Widdel, F. (1994). Anaerobic oxidation of ferrous iron by purple bacteria, a new type of phototrophic metabolism. Appl Environ Microbiol 60, 4517-4526.

Eichler, B. \& Pfennig, N. (1986). Characterization of a new plateletforming purple sulfur bacterium, Amoebobacter pedioformis sp. nov. Arch Microbiol 146, 295-300.

Eichler, B. \& Pfennig, N. (1988). A new purple sulfur bacterium from stratified freshwater lakes, Amoebobacter purpureus sp. nov. Arch Microbiol 149, 395-400.

Fitch, W. M. \& Margoliash, E. (1967). Construction of phylogenetic trees. Science 155, 279-284.

Golecki, J. R. \& Heinrich, U.-R. (1991). Ultrastructural and electron spectroscopic analyses of cyanobacteria and bacteria. J Microsc 162, $147-154$.

Guyoneaud, R., Süling, J., Petri, R., Matheron, R., Caumette, P., Pfennig, N. \& Imhoff, J. F. (1998). Taxonomic rearrangements of the genera Thiocapsa and Amoebobacter on the basis of $16 \mathrm{~S}$ rDNA sequence analyses, and description of Thiolamprovum gen. nov. Int J Syst Bacteriol 48, 957-964.

Imhoff, J. F. (2001). Transfer of Pfennigia purpurea Tindall 1999 (Amoebobacter purpureus Eichler and Pfenning 1988) to the genus Lamprocystis as Lamprocystis purpurea comb. nov. Int J Syst Evol Microbiol 51, 1699-1701.

Imhoff, J. F. \& Trüper, H. G. (1992). The genus Rhodospirillum and related genera. In The Prokaryotes: a Handbook on the Biology of Bacteria-Ecophysiology, Isolation, Identification, Applications, pp. 2141-2155. Edited by A. Balows, H. G. Trüper, M. Dworkin, W. Harder \& K. H. Schleifer. Berlin: Springer.

Imhoff, J. F., Süling, J. \& Petri, R. (1998). Phylogenetic relationships among the Chromatiaceae, their taxonomic reclassification and description of the new genera Allochromatium, Halochromatium, Isochromatium, Marichromatium, Thiococcus, Thiohalocapsa and Thermochromatium. Int J Syst Bacteriol 48, 1129-1143.

Janssen, P. H. \& O'Farrell, K. A. (1999). Succinispira mobilis gen. nov., sp. nov., a succinate-decarboxylating anaerobic bacterium. Int $J$ Syst Bacteriol 49, 1009-1013.

Janssen, P. H., Liesack, W., Kluge, C., Seeliger, S., Schink, B. \& Harfoot, C. G. (1996). Sodium-dependent succinate decarboxylation by a new anaerobic bacterium belonging to the genus Peptostreptococcus. Antonie Leeuwenhoek 70, 11-20.

Jukes, T. H. \& Cantor, C. R. (1969). Evolution of protein molecules. In Mammalian Protein Metabolism, vol. 3, pp. 21-132. Edited by H. N. Munro. New York: Academic Press.

Kuenen, J. G. \& Beudeker, R. F. (1982). Microbiology of thiobacilli and other sulphur-oxidizing autotrophs, mixotrophs and heterotrophs. Philos Trans R Soc Lond B Biol Sci 298, 473-497.
Littlejohn, T. G., Bucholtz, C. A., Campbell, R. M. M., Gaeta, B. A., Huynh, C. \& Kim, S. H. (1996). Computing for biotechnology - Web ANGIS. Australas Biotechnol 6, 211-217.

Neefs, J.-M., Van de Peer, Y., De Rijk, P., Chapelle, S. \& De Wachter, R. (1993). Compilation of small ribosomal subunit RNA structures. Nucleic Acids Res 21, 3025-3049.

Ostle, A. G. \& Holt, J. G. (1982). Nile blue A as a fluorescent stain for poly- $\beta$-hydroxybutyrate. Appl Environ Microbiol 44, 238-241.

Overmann, J., Beatty, J. T., Krouse, H. R. \& Hall, K. J. (1996). The sulfur cycle in the chemocline of a meromictic salt lake. Limnol Oceanog 41, 147-156.

Pfennig, N. (1978). Rhodocyclus purpureus gen. nov. and sp. nov., a ring-shaped, vitamin $\mathrm{B}_{12}$-requiring member of the family Rhodospirillaceae. Int J Syst Bacteriol 28, 283-288.

Pfennig, N. (1987). Ecology of phototrophic purple and green sulfur bacteria. In Autotrophic Bacteria, pp. 97-116. Edited by H. G. Schlegel $\&$ B. Bowien. Madison, WI: Science Tech Publishers.

Pfennig, N. \& Trüper, H. G. (1992). The family Chromatiaceae. In The Prokaryotes: a Handbook on the Biology of Bacteria-Ecophysiology, Isolation, Identification, Applications, pp. 3200-3221. Edited by A. Balows, H. G. Trüper, M. Dworkin, W. Harder \& K. H. Schleifer. Berlin: Springer.

Pfennig, N., Markham, M. C. \& Liaaen-Jensen, S. (1968). Carotenoids of Thiorhodaceae. 8. Isolation and characterization of a Thiothece, Lamprocystis and Thiodictyon strain and their carotenoid pigments. Arch Mikrobiol 62, 178-191.

Rees, G. N., Grassia, G. S., Sheehy, A. J., Dwivedi, P. P. \& Patel, B. K. C. (1995). Desulfacinum infernum gen. nov., sp. nov., a thermophilic sulfate-reducing bacterium from a petroleum reservoir. Int J Syst Bacteriol 45, 85-89.

Shively, J. M., Ball, F. L. \& Kline, B. W. (1973). Electron microscopy of the carboxysomes (polyhedral bodies) of Thiobacillus neapolitanus. $J$ Bacteriol 116, 1405-1411.

Sorokin, Y. I. (1970). Interrelations between sulphur and carbon turnover in meromictic lakes. Arch Hydrobiol 66, 391-446.

Takahashi, M. \& Ichimura, S. (1970). Photosynthetic properties and growth of photosynthetic sulfur bacteria in lakes. Limnol Oceanog 15, 929-944.

Tindall, B. J. (1999). Taxonomic note: transfer of Amoebobacter purpureus to the genus Pfennigia gen. nov., as Pfennigia purpurea comb. nov., on the basis of the illegitimate proposal to make Amoebobacter purpureus the type species of the genus Amoebobacter. Int J Syst Bacteriol 49, 1307-1308.

Vainshtein, M., Suzina, N. \& Sorokin, V. (1997). A new type of magnet-sensitive inclusions in cells of photosynthetic purple bacteria. Syst Appl Microbiol 20, 182-186.

Widdel, F. \& Bak, F. (1992). Gram-negative mesophilic sulfatereducing bacteria. In The Prokaryotes: a Handbook on the Biology of Bacteria-Ecophysiology, Isolation, Identification, Applications, pp. 3352-3378. Edited by A. Balows, H. G. Trüper, M. Dworkin, W. Harder \& K. H. Schleifer. Berlin: Springer.

Yakimov, M. M., Golyshin, P. N., Lang, S., Moore, E. R. B., Abraham, W.-R., Lünsdorf, H. \& Timmis, K. N. (1998). Alcanivorax borkumensis gen. nov., sp. nov., a new, hydrocarbon-degrading and surfactant-producing marine bacterium. Int $J$ Syst Bacteriol 48, 339-348. 